Journal of Aafiyah Health Research (JAHR)

P-ISSN: 2722-4929 \& E-ISSN: 2722-4945

Published by Postgraduate Program in Public health, Muslim University of Indonesia

Original Research

Open Access

\title{
Metode Edukasi Discussion Group Melalui Whatsapp Terhadap Pengetahuan Tentang Kesehatan Gigi dan Mulut Pada Usia Lanjut Anggota Pronalis
}

\author{
*M Rizky Adipratama ${ }^{1}$, Nurmiati Muchlis ${ }^{2}$, Jasmin Ambar $^{3}$, Yusriani ${ }^{4}$ \\ ${ }^{1}$ Klinik Parakita Medika Makassar \\ ${ }^{2}$ Fakultas Kesehatan Masyarakat, Universitas Muslim Indonesia \\ ${ }^{3,4}$ Program Pascasarjana Kesehatan Masyarakat, Universitas Muslim Indonesia \\ *Email: muhrizkyadipratamayusuf@gmail.com
}

\begin{abstract}
ABSTRAK
Latar belakang: Kesehatan rongga mulut memegang peranan penting dalam mendapatkan kesehatan umum dan kualitas hidup seseorang. Berdasarkan teori Blum, status kesehatan gigi dan mulut seseorang atau masyarakat dipengaruhi oleh empat faktor penting yaitu keturunan, lingkungan (fisik maupun sosial budaya), perilaku, dan usia. Pada usia lanjut dengan riwayat hipertensi dan DM Tipe 2 sangat sering ditemukan pasien yang datang kedokter gigi dengan keadaan gigi goyang ataupun berlubangyang diakibatkan oleh Oral Hygine buruk. Hal ini terjadi karena kurangnya pengetahuan usia lanjut tentang pentingnya menjaga kesehatan gigi dan mulut. Mengetahui pengaruh edukasi discussion group melalui WhatsApp terhadap pengetahuan tentang kesehatan gigi dan mulut pada usia lanjut. Metode: Jenis penelitian menggunakan metode observasional analitik dengan rancangan studi quasi eksperimental. Metode pengambilan sampel menggunakan exhaustic sampling, dilakukan pada 60 usia lanjut anggota prolanis puskesmas bira dan puskesmas kapasa kota makassar yang telah memenuhi kriteria. Pada pengukuran tingkat pengetahuan dan sikap usia lanjut ini diukur menggunakan pengisian kuisioner. Hasil: Uji Pearson's Correlation menunjukkan bahwa terdapat pengaruh pemberian edukasi discussion group melalui Whatsapp terhadap pengetahuan tentang kesehatan gigi dan mulut pada usia lanjut $(\mathrm{p}=$ 0,001; $\mathrm{p}<0,05)$ dan $\mathrm{r}=0,429$ yang berarti bahwa tingkat korelasi cukup. Kesimpulan: Pemberian edukasi discussion group melalui WhatsApp dapat digunakan sebagai metode edukasi karena berdasarkan hasil penelitian terdapat korelasi yang signifikan antara pemberian edukasi terhadapt peningkatan pengetahuan dengan tingkat korelasi yang cukup.
\end{abstract}

Kata Kunci: Kesehatan gigi dan mulut, usia lanjut, whatsaap 


\begin{abstract}
Background: Oral health plays an important role in getting a person's general health and quality of life. Based on Blum's theory, the oral health status of a person or society is influenced by four important factors, namely heredity, environment (physical and sociocultural), behavior, and age. In the elderly with a history of hypertension and Type 2 diabetes mellitus, it is very common to find patients who come to the dentist with loose or perforated teeth caused by poor Oral Hygine. This occurs due to the lack of knowledge of the elderly about the importance of maintaining healthy teeth and mouth. Knowing the effect of discussion group education through WhatsApp on knowledge about dental and oral health in the elderly. Methods: This type of research uses an analytic observational method with a quasi experimental study design. The sampling method used exhaustic sampling, carried out on 60 elderly members of the prolanis of the Bira Health Center and the Kapasa Public Health Center in Makassar City who had met the criteria. In measuring the level of knowledge and attitudes of elderly people, it is measured using questionnaires. Results: Pearson's Correlation test shows that there is an effect of providing discussion group education via Whatsapp on knowledge about oral health in the elderly $(p=0.001 ; p$ $<0.05$ ) and $r=0.429$, which means that the level of correlation is sufficient. Conclusion: The provision of discussion group education through WhatsApp can be used as an educational method because based on the results of the study there is a significant correlation between the provisions of education to increasing knowledge with a sufficient level of correlation.
\end{abstract}

Keywords: Teeth and Oral hygiene, elderly, whatsapp, education

\section{LATAR BELAKANG}

Melaksanakan pembangunan di bidang kesehatan, pembangunan di bidang kesehatan gigi adalah salah satu hal yang sangat penting. Namun, saat ini kesadaran masyarakat Indonesia akan pentingnya memiliki kualitas gigi dan mulut yang sehat masih kurang. Gigi berlubang atau disebut karies ditandai dengan kerusakan struktur gigi sehingga menyebabkan terbentuknya lubang pada gigi. Apabila tidak ditangani segera, penyakit ini lama kelamaan dapat menimbulkan nyeri, rasa sakit, dan kehilangan gigi bahkan menjadi pemicu timbulnya berbagai penyakit berbahaya. Beberapa studi melaporkan adanya hubungan antara penyakit gigi dengan penyakit jantung koroner, aterosklerosis, pneumonia, diabetes dan kelahiran premature (1).

Menurut WHO usia lanjut meliputi : Usia pertengahan adalah kelompok usia 45-59 tahun, lansia adalah kelompok usia antara 60-70 tahun, lansia tua adalah kelompok usia antara 75-90 tahun, usia sangat tua adalah kelompok usia di atas 90 tahun. Kelompok lansia dibagi menjadi dua yaitu yang produktif, dimana usia 50-64 tahun dan yang non produktif diatas 65 tahun. Berdasarkan proyeksi di tahun 2010-2035 kelompok usia lansia yang produktif dan non produktif akan terus meningkat (2).

Berdasarkan data UNFPA, di dunia saat ini terdapat sekitar 737 juta jiwa penduduk lanjut usia (lansia), yaitu usia 
60 tahun lebih. Data BPS tahun 2010 mencatat jumlah penduduk Indonesia yaitu sebanyak 237.641.326 jiwa dan sekitar 20 juta atau 9,6\% dari jumlah penduduk Indonesia adalah penduduk usia lanjut. Indonesia akan mengalami peningkatan jumlah populasi usia lanjut yang luar biasa pada tahun 2025 diproyeksikan sebesar 414\%, ini terbesar di dunia. Lanjut usia adalah setiap rang yang berusia 60 tahun atau lebih, yang secara fisik terlihat berbeda dengan kelompok umur lainnya. Umumnya setiap orang akan mengalami proses menjadi tua dan masa tua adalah masa hidup manusia yang terakhir (3).

Berdasarkan data yang didapat dari Riset Kesehatan Dasar bahwa sebesar 25,9\% penduduk Indonesia mempunyai masalah kesehatan gigi dan mulut dalam 12 bulan terakhir. Angka prevalensi tertinggi terhadap masalah kesehatan gigi dan mulut terdapat di provinsi Sulawesi Selatan 36,2\% diikuti Kalimantan Selatan 36,1\%, Sulawesi Tengah 35,6\%, Sulawesi Barat 32,2\%, DI Yoyakarta $32,1 \%$, Sulawesi Utara 31,6\% (4).

Berdasarkan teori Blum, status kesehatan gigi dan mulut seseorang atau masyarakat dipengaruhi oleh empat faktor penting yaitu keturunan, lingkungan (fisik maupun sosial budaya), perilaku, dan usia (Nayoan, 2015). Lebih lanjut, kesehatan rongga mulut memegang peranan penting dalam mendapatkan kesehatan umum dan kualitas hidup usia lanjut. Keadaan mulut yang buruk misalnya banyakanya gigi yang hilang dan tidak dirawat akan mengganggu fungsi dan aktivitas rongga mulut (Wibisono, 2010). Pada usia lanjut dengan riwayat hipertensi dan DM Tipe 2 sangat sering ditemukan pasien yang datang kedokter gigi dengan keadaan gigi goyang ataupun berlubang. Salah satu penyebab terjadinya gigi berlubang adalah Xerostomia, yang terjadi karena karena hiperglikemia yang mengakibatkan meningginya jumlah urin sehingga cairan dalam tubuh dan sekresi saliva berkurang. Oral hygine juga berperan penting pada kasus terjadinya gigi berlubang pada individu terutama pada usia lanjut yang kurang menjaga kebersihan gigi dan mulutnya. Dengan oral hygine yang buruk dapat mengakibatkan terjadinya akumulasi plak dan kalkulus penyebab gigi berlubang karena infasi bakteri selain itu dapat mengakibatkan terjadinya penyakit gingivitis dan periodontitis yang dapat membuat gigi kehilangan perlekatan jaringan pendukungnya dan mengakibatkan kegoyangan pada gigi hingga gigi tanggal sebelum waktunya (5).

Selain kondisi rongga mulut yang dapat terjadi karena adanya penyakit sistemik pada usia lanjut, juga bisa terjadi beberapa kasus lainnya yang dapat membahayakan usia lanjut pada saat ingin melakukan pencabutan gigi salah satunya adalah infeksi odontogen yang secara tidak langsung dapat berimbas pada jantung penderita. Infeksi odontogen merupakan infeksi rongga mulut yang paling sering terjadi. Infeksi odontogenik dapat merupakan awal atau kelanjutan penyakit periodontal, 
perikoronal, trauma, atau infeksi pasca pembedahan (6).

Selama ini, pada program prolanis yang diterapkan di Puskesmas berupa kegiatan Senam dan pemberian edukasi. Dimana pemberian edukasi pada prolanis dilakukan dengan metode one way (ceramah) sehingga proses pemberian edukasi hanya berjalan satu arah yang memungkinkan anggota prolanis masih kurang memahami edukasi yang diberikan dan berakibat pada implementasi sehari-harinya yang kurang efektif. Oleh karena itu, diharapkan dengan edukasi menggunakan metode two way dapat menjadi solusi yang tepat unuk pemberian edukasi oleh petugas prolanis kepada anggota prolanis sehingga anggota prolanis dapat lebih memahami dan diharapkan dapat meningkatkan taraf kesehatan gigi dan mulut anggota prolanis di Indonesia (7).

\section{METODE}

Penelitian ini mengacu pada pendekatan penelitian kuantitatif dengan jenis penelitian yang digunakan yaitu penelitian quasi eksperimental design. Penelitian ini dilakukan di wilayah kerja Puskesmas Bira dan Puskesmas Kapasa Kota Makassar. Dengan pertimbangan bahwa Puskesmas Bira dan Puskesmas Kapasa rutin melakukan pemeriksaan usia lanjut yang dilaksanakan setiap bulannya dari umur $>45$ tahun. Serta kegiatan senam bersama dilakukan setiap akhir pekan.

Adapun, populasi penelitian ini berasal dari Anggota Program Penyakit Kronis
Puskesmas Bira Kota Makassar dan Puskesmas Kapasa Kota Makassar. Sampel penelitian ini berjumlah 60 orang yang terdiri dari 30 orang dari Puskesmas Bira dan 30 orang dari Puskesmas Kapasa. Adapun Teknik pengambilan sampel dalam penelitian ini adalah exhaustic sampling. Menurut Murti (2006) exhaustive sampling yaitu teknik memilih sampel dengan melakukan survei kepada seluruh populasi yang ada atau mengambil semua anggota populasi sebagai sampel (8).

Eksperimen design dalam kelompok ini terdiri dari dua kelompok yaitu kelompok intervensi yang berjumlah 30 dari puskesmas bira yang memperoleh edukasi terkait kesehatan gigi dan mulut. Penyuluhan dilakukan melalui group whatsapp oleh dokter gigi. Sebelum dilakukan edukasi, evaluasi terhadap sikap dan pengetahuan dilakukan pada kelompok intervensi. Sedangkan, kelompok kontrol (tidak memperoleh intervensi) yang terdiri dari 30 orang yang berasal dari puskesmas Kapasa.

Pengumpulan data dilakukan sejak bulan Mei sampai Juni 2020 tentang Pengaruh Metode Edukasi Discussion Group Melalui WhatsApp dan pengisian koesioner dilakukan melalui Google form. Kemudian, data analisis dilakukan dengan software Statistical Product and Service Solution (SPSS) versi 2.3 menggunakan uji Independent Sample TTest dan Korelasi Pearson. 
HASIL

Berdasarkan hasil perhitungan independent sample t-test pada table 1 pengetahuan diketahui nilai rata-rata kenaikan pengetahuan kelompok intervensi sebesar 6,77 sedangkan kenaikan kelompok kontrol sebesar 5,23 sehingga diketahui kenaikan skor pengetahuan kelompok intervensi lebih besar 1,54 dibandingkan dengan skor kelas kontrol. Diketahui juga nilai $\mathrm{t}$ hitung sebesar 3,613 dengan signifikansi 0,001 . Nilai $\mathrm{t}$ tabel dari df 58 adalah 1,672. Jadi dapat disimpulkan bahwa $\mathrm{t}$ hitung $>\mathrm{t}$ tabel $(3,613>1,672)$ dan nilai signifikansinya kurang dari 0,05 (sig = $0,001<0,05$ ), sehingga dapat dinyatakan terdapat perbedaan yang signifikan dalam peningkatan skor hasil belajar secara signifikan pada kelompok intervensi dan kelompok kontrol.

Tabel 1. Uji Independent Samples T-Test

\begin{tabular}{llccc}
\hline \multirow{2}{*}{ Kelompok } & \multicolumn{2}{c}{ Mean } & \multirow{2}{*}{ p value } \\
\cline { 3 - 4 } Pengetahuan & Intervensi & Pre-test & Post-test & \\
\cline { 2 - 4 } Kontrol & 5,30 & 6,77 & \\
& & 5,23 & 5,23 & 0,001
\end{tabular}

Sumber : data primer diolah dengan SPSS 23, 2020

Berdasarkan hasil uji Pearson antara pengetahuan koresponden dengan metode Education Discussion Group diketahui nilai $\mathrm{r}$ hitung sebesar 0,429 dengan signifikansi 0,001 . Nilai $r$ tabel dari df 58 adalah 0,254. Jadi dapat disimpulkan bahwa $\mathrm{r}$ hitung $>\mathrm{r}$ tabel $(0,429>0,254)$ dan nilai signifikansinya kurang dari $0,05(\operatorname{sig}=0,001<0,05)$, sehingga dapat dinyatakan terdapat korelasi yang signifikan antara variabel pengetahuan dengan variabel kelompok intervensi dan kontrol melalui metode Education Discussion Group. Dengan besarnya korelasi adalah 0,429 yang artinya memiliki korelasi yang cukup.

Tabel 2. Uji Pearson Correlation

\begin{tabular}{ccccc}
\hline & Pengetahuan & Sikap & Kelompok & P Value \\
\hline Pengetahuan & 1 & 0.325 & 0.429 & \\
& & & & 0,001 \\
Kelompok & 0.429 & 0.845 & 1 &
\end{tabular}

Sumber : Data Primer, 2020

Untuk hasil uji pearson antara sikap koresponden dengan metode Education Discussion Group diketahui nilai $\mathrm{r}$ hitung sebesar 0,845 dengan signifikansi 0,000 . Nilai $r$ tabel dari df 58 adalah 0,254. Jadi dapat disimpulkan bahwa $r$ hitung $>r$ tabel $(0,845>0,254)$ dan nilai signifikansinya kurang dari 0,05 
$(\operatorname{sig}=0,000<0,05)$, sehingga dapat dinyatakan terdapat korelasi yang signifikan antara variabel sikap dengan variabel kelompok intervensi dan kontrol melalui metode Education Discussion Group. Dengan besarnya korelasi adalah 0,845 yang artinya memiliki korelasi yang sangat kuat.

\section{PEMBAHASAN}

Akibat bertambahnya usia juga dapat menyababkan kehilangan gigi secara berangsur-angsur karena tanggal. Ketidaklengkapan gigi tentunya akan dapat mengurangi kenyamanan makan dan membatasi jenis-jenis makanan yang dikonsumsi. Produksi air liur dengan berbagai enzim yang dikandungnya juga mengalami penurunan, sebagai akibatnya dapat menimbulkan mulut kering, kemampuan mengecap makanan berkurang, dan kemungkinan mempercepat terjadinya penimbunan karang gigi. Faktor-faktor penting yang dapat mempengaruhi kesehatan gigi pada usia lanjut di antaranya adalah kurangnya produksi saliva serta kebiasaan membersihkan gigi dan mulut. Karies gigi dan penyakit periodontal merupakan penyebab utama kehilangan gigi pada lansia (8).

Kurang menjaga kebersihan gigi bisa berimplikasi masuknya bakteri yang berujung pada banyak masalah kesehatan yang umum seperti penyakit jantung dan penyakit lainnya. Penyakit di rongga mulut pada usia lanjut dapat berakibat negatif terhadap kesehatan dan kualitas hidup usia lanjut secara keseluruhan. Beberapa kondisi yang sering terjadi pada rongga mulut usia lanjut seperti: kehilangan gigi, penyakit gusi, mulut kering/xerostomia dan periodontitis. Melalui perawatan yang baik gigi dapat bertahan selama mungkin di rongga mulut (9).

Status kesehatan gigi usia lanjut dipengaruhi oleh beberapa faktor yang saling berinteraksi: 1) Faktorisepidari diri lansia sendiri, berupa: jenis kelamin, usia, perilaku hidup, pendidikan, pekerjaan, status perkawinan, perumahan, dan status sosial ekonomi, 2) Faktor keluarga, seperti: jumlah generasi, pola tinggal, dan peri-laku keluarga dalam pemeliharaan kesehatan gigi; 3) Faktor lingkungan, seperti keadaan sosial budaya; Faktor pelayanan kesehatan gigi, berupa: keberadaan program kesehatan gigi lansia, sikap dan perilaku petugas kesehatan saat memberikan pelayanan kesehatan (10).

Selain para usia lanjut yang dapat menjaga kesehatan gigi dan mulutnya sendiri, peran keluarga dan petugas kesehatan juga sangat penting. Dalam hal ini peran petugas kesehatan dapat melakukan upaya promotif, preventif, kuratif dan rehabilitatif. Untuk upaya promotif dan preventif dapat dilakukan oleh petugas prolanis (10).

Kegiatan Prolanis merupakan sistem pelayanan kesehatan yang dilaksanakan secara terintegratif yang melibatkan peserta, fasilitas kesehatan, dan BPJS Kesehatan untuk pemeliharaan kesehatan agar mencapai kualitas hidup yang optimal dengan biaya pelayanan kesehatan yang efektif dan efisien. 
Sasaran dari kegiatan Prolanis adalah seluruh peserta BPJS Kesehatan penyandang penyakit kronis khusunya DM Tipe II dan Hipertensi (11).

Adapun tujuan bentuk kegiatan prolanis seperti pemberian edukasi kesehatan/penyuluhan. Manfaat pemberian edukasi bagi peserta Prolanis antara lain meningkatkan pengetahuan pasien tentang sakitnya yang pada akhirnya akan meningkatkan derajat kesehatannya. Hal ini sesuai dengan teori yang menyatakan bahwa manfaat pemberian pendidikan bagi pasien antara lain meningkatkan pengetahuan, kesadaran dan ketrampilan pasien dalam upaya mempertahankan dan meningkatkan kesehatan, meningkatkan kepuasan pasien terhadap pelayanan kesehatan dan mencegah komplikasi penyakit (12).

Berdasarkan hasil penelitian yang didapatkan untuk mengukur tingkat pengetahuan usia lanjut terhadap kesehatan gigi dan mulut, didapatkan peningkatan skor sebesar 1,47. Dimana nilai sebelum pemberian edukasi didapatkan skor 5,30 dan menjadi 6,77 setelah pemberian edukasi. Sedanngkan kelompok lansia tanpa pemberian edukasi tida mengalami peningkatan skor.

Menurut peneliti, hal ini dapat terjadi karena sampel penelitian dalam hal ini anggota prolanis dapat mengerti dan memahami pemberian informasi oleh peneliti mengenai pentingnya menjaga kesehatan gigi dan mulut pada usia lanjut, sehingga terjadi kenaikan skor.
Secara teori juga dijelaskan, perubahan perilaku seseorang menerima atau mengadopsi perilaku baru dalam kehidupannya melalui tiga tahap, yaitu pengetahuan yaitu sebelum seseorang mengadopsi perilaku (berperilaku baru), ia harus tahu terlebih dahulu apa arti atau manfaat perilaku tersebut bagi dirinya atau keluarganya, sikap yaitu setelah seseorang mengetahui stimulus atau objek, proses selanjutnya akan menilai atau bersikap terhadap stimulus atau objek kesehatan tersebut, praktik atau tindakan yaitu setelah seseorang mengetahui stimulus atau objek kesehatan, kemudian mengadakan penilaian atau pendapat terhadap apa yang diketahui atau disikapinya (13).

Pengetahuan adalah hasil dari tahu dan ini terjadi setelah orang melakukan pengindraan terhadap suatu obyek tertentu. Pengindraan terjadi melalui pancaindra manusia, yakni indra pengelihatan, pendengaran, penciuman, rasa, dan raba dengan sendiri. Sebagaian besar pengetahuan manusia diperoleh melalui mata dan telinga. Adapun pengetahuan memiliki 6 tingkatan, tahu (know), memahami (comprehension), aplikasi (application), analisis (analysis), sintesis (synthesis), dan evaluasi (evaluation). Pengetahuan pada seseorang tidak hanya diperoleh melalui sebuah pendidikan formal saja, tetapi juga dapat diperoleh melalui pendidikan non-formal. Tetapi Semakin tinggi pendidikan seseorang maka semakin mudah pula mereka menerima informasi dan makin banyak pula pengetahuan yang dimilikinya. Sebaliknya, jika seseorang 
memiliki tingkat pendidikan rendah maka akan menghambat perkembangan perilaku seseorang terhadap penerimaan, informasi dan nilai yang baru diperkenalkan (14).

Selain pengetahuan yang didapatkan dari pendidikan ada juga pengetahuan yang didapatkan dari pengalaman. Pengalaman adalah suatu kejadian yang pernah dialami seseorang dalam berinteraksi dengan lingkungannya. Kecenderungan pengalaman yang kurang baik akan berusaha untuk dilupakan oleh seseorang. Namun jika pengalaman terhadap obyek tersebut menyenangkan maka secara psikologis akan timbul kesan yang sangat mendalam dan membekas dalam emosi kejiwaannya dan akhirnya dapat pula membentuk sikap positif dalam kehidupannya (13).

Pengetahuan yang dimiliki seseorang mengandung aspek positif dan negatif yang dapat menentukan sikap seseorang terhadap suatu objek tertentu (Riyanto \& Budiman, 2013). Pendidikan mempunyai efek yang positif terhadap kesadaran terhadap kesehatan dan berpengaruh pada perilaku kesehatan (15).

Hal ini sejalan dengan penelitian yang dilakukan oleh Desi Sandra, dkk (2015) di Jember, Jawa Timur dengan jumlah populasi 80 orang usia lanjut yang terdiri dari 31 pria dan 49 wanita serta penelitian yang dilakukan oleh Bunga (2017) di Surakarta, Jawa Tengah dengan jumlah populasi 60 orang usia lanjut yang terdiri dari 23 pria dan 37 wanita. Berdasarkan penelitian tersebut didapatkan bahwa ada hubungan yang bermakna antara tingkat pengetahuan kesehatan gigi dan mulut dengan tingkat kebersihan mulut usia lanjut (16).

Berdasarkan hasil penelitian yang didapatkan untuk mengukur sikap usia lanjut terhadap kesehatan gigi dan mulut, didapatkan peningkatan skor sebesar 6,73. Dimana nilai sikap usia lanjut sebelum pemberian edukasi didapatkan skor 26,37 dan menjadi 33,10 setelah pemberian edukasi. Sedanngkan kelompok lansia tanpa pemberian edukasi tida mengalami peningkatan skor.

Menurut peneliti, hal ini dapat terjadi karena sampel penelitian dalam hal ini anggota prolanis selalu didampingi dan mendapat support dari angota keluarga sehinga dapat terjadi perubahan sikap.

\section{KESIMPULAN}

Berdasarkan hasil penelitian dan pembahasan, maka diperoleh kesimpulan bahwa terdapat pengaruh pemberian edukasi dengan metode discussion group terhadap pengetahuan anggota prolanis di Puskesmas Bira Kota Makassar dengan rata-rata nilai 6,77 dibandingkan dengan nilai rata-rata Puskesmas Kapasa Kota Makassar sebesar 5,23. (p-value: 0,001).2). Berdasarkan hasil analisis menggunakan uji Pearson correlation didapatkan korelasi yang signifikan antara pemberian edukasi terhadap peningkatan pengetahuan ( $\mathrm{p}$ value 0,001 $<\alpha 0,01)$. 
Saran

Penelitian selanjutnya diharapkan untuk mengadakan penelitian sejenis lebih lanjut dengan mengambil wilayah penelitian yang lebih luas, sampel yang lebih banyak dan menggunakan rancangan penelitian yang lebih kompleks seperti eksperimen, etnografi dan lainnya, menggunakan variabel yang lebih banyak lagi. Saran untuk puskesmas, pihak poliklinik gigi Puskesmas agar meningkatkan penyuluhan kesehatan khususnya penyuluhan tentang pentingnya menjaga kesehatan gigi dan mulut pada usia lanjut anggota program pengelolaan penyakit kronis. Baik pada saat konseling/penyuluhan maupun dengan memberikan leaflet ataupun media penyuluhan yang lebih menarik dan mudah dipahami oleh lansi anggota prolanis dan seluruh pasien gigi mulut yang berkunjung. Bagi masyarakat, diharapkan kepada masyarakat agar tidak melupakan kewajiban untuk terus memeriksakan kesehatan gigi dengan tidak menunggu sakit, serta menanamkan dalam diri tentang betapa pentingnya pencegahan sakit gigi sejak dini. Oleh karna itu sangat dianjurkan kepada masyarakat terus menambah pengetahuan terhadap pemanfaatan pelayanan kesehatan gigi.

\section{DAFTAR PUSTAKA}

1. Pintauli, S. Dan Hamada, T. 2010. Menuju Gigi dan Mulut Sehat: Pencegahan dan Pemeliharaan. Medan: USU Press: 1-20.
2. Hasibuan, W., Ismayadi. 2010.Laporan Penelitian: Hubungan Program Pelayanan Posyandu Usia lanjut terhadap Tingkat Kepuasan Usia lanjut di Daerah Binaan Puskesmas 3 Darussalam, Medan. Medan: PSIK FK USU.

3. Senjaya, Asep Arifin., 2016. Gigi Usia lanjut. Jurusan Keperawatan Gigi Politeknik Kesehatan Denpasar. Jurnal Skala Husada Volume 13 Nomor 1 April 2016: 7280

4. (Riskesdas, 2013).

5. Caranza, Newman. 2015.Clinical Periodontology. Elsevier. Philadelphia. hal: 57-69, 531-536, 540-542, 546, 605, 663.

6. Wazir,D., S. Ahmad, R.Muse, M. Mahmood, M.Y. Antioxidant Activities of Different Parts of Gnetum Gnemon L.Journal Plants Biochemistry and Biotechnology. 20 (2):234-240.

7. Maryam, S., 2015. Promosi Kesehatan, EGC, Jakarta, h. 11-12, 19, 21, 33, 133-134.

8. Murti B. 2006. Desain dan Ukuran Sampel Untuk Penelitian Kuantitatif dan Kualitatif di Bidang Kesehatan. Yogyakarta : Gadjah Mada Universitas Press

9. Sanjaya, Asep., Gigi Lansia. 2016: Jurnal Skala Husada Volume 13 No.1 April:72-80.

10. Rahardjo dan Tri B. W. Kebijakan Tentang Kesejahteraan Penduduk Lansia Di Indonesia Serta Kaitannya Dengan Upaya Pembinaan 
Kesehatan, Termasuk Bidang Kesehatan Gigi, Majalah Ilmiah Kedokteran Gigi 1 (Edisi Khusus Foril V 1996), hal. 68-78. 1996.

11. BPJS. 2015. Panduan praktis PROLANIS (Program pengelolaan penyakit kronis). In BPJS Kesehatan. Jakarta: badan penyelenggara jaminan sosial kesehatan.

12. Demiyanti, Emi., dkk. Pengaruh Edukasi Kelompok pada Pengendalian Tekanan Darah di Anggota Klub Prolanis Klinik Pratama. Dept Ilmu Kesehatan Masyarakat Fakultas Kedokteran Universitas Padjajaran, Volume 4 No.2 Des: 2018. p 48-50.

13. Notoatmodjo, S. 2013. Pendidikan dan Perilaku Kesehatan. Jakarta : Rineka Cipta

14. Budiharto, 2010. Pengantar Ilmu Perilaku Kesehatan dan Pendidikan Kesehatan Gigi. Jakarta: EGC. p.139-147.

15. Notoatmodjo, S. 2012. Promosi kesehatan dan Perilaku Kesehatan. Jakarta: Rineka cipta, p. 123-129.

16. Desi Sandra, dkk., 2015, Hubungan Pengetahuan Kesehatan Gigi Dan Mulut Dengan Status Kebersihan Rongga Mulut Pada Lansia 4(1), Jurnal IKESMA Volume 11 Nomor 1 Maret 2015.

17. Elisa. 2017. Psikologi Keperawatan. Yogyakarta : Pustaka Baru.

18. Wawan A dan Dewi M, (2010). Teori dan Pengukuran Pengetahuan, Sikap dan Perilaku manusia. Yogyakarta: Nuha Medika.
19. Nurhamsyah, Donny, dkk. Pengaruh Edukasi terhadap Perubahan Pengetahuan dan Sikap Mahasiswa tentang TRIAD Kesehatan Reproduksi Remaja (KRR) di Fakultas Ilmu Sosial dan Ekonomi Universitas Respati Yogyakarta. Jurnal Keperawatan Respati, 2 (2). 2015.

20. Pratiwi Hening, dkk. 2016. Pengaruh Edukasi Terhadap Pengetahuan, Sikap, Dan Kemampuan Berkomunikasi Atas Informasi Obat. Jurnal Ilmiah Farmasi

21. Schwarz E, Dental health knowledge and attitudes among the middleaged and the elderly in Hong Kong, Community Dent Oral Epidemiology 1994; 22: 358-63.

22. Maryam, S., 2015. Promosi Kesehatan, EGC, Jakarta, h. 11-12, 19, 21, 33, 133-134.

23. Riyanto, Agus., 2013. Kuesioner Pengetahuan dan Sikap Dalam Penelitian Kesehatan. Jakarta: Salemba Medika, p: 66-69.

24. Green, Lawrence, 1980. Health Education: A Diagnosis Approach, The John Hopkins University, Mayfield Publishing Co. 103(2), 137- 149.

25. Yusriani, Y.; Alwi, M. K. Buku ajar promosi kesehatan dan pemberdayaan masyarakat. Book \& Articles Of Forikes, 2018, 9: 1-59.

26. Adelina N, Fitriana F, Naid T, Seniwati $\mathrm{S}$, Septiyanti S. Isolation and Test of Anti-Bacterial Activity of Endophytic Fungi in Clove 
Flowers (Syzygium aromaticum L.) in Inhibiting Bacteria Causes of Dental Caries. Window of Health : Jurnal Kesehatan [Internet]. 24Apr.2019 [cited 25Aug.2020];:148-54. Available from:

http://jurnal.fkmumi.ac.id/index.php /woh/article/view/woh2206

27. Maulidiyah Z, Dali S, Rusli R, Naid T. Isolasi Bakteri Rhizosfer
Tanaman Nilam (Pogostemon cablin Benth.) yang Berpotensi sebagai Penghasil Senyawa Antibakteri terhadap Bakteri Penyebab Infeksi Saluran Pencernaan. Window of Health : Jurnal Kesehatan [Internet]. 25Apr.2020 [cited 25Aug.2020];:132-9. Available from:

http://jurnal.fkmumi.ac.id/index.php /woh/article/view/295 